\title{
Associations between Obesity and Spinal Diseases: A Medical Expenditure Panel Study Analysis
}

\author{
Binwu Sheng ${ }^{1, *,+}$, Chaoling Feng ${ }^{2}$, Donglan Zhang ${ }^{3}$, Hugh Spitler ${ }^{4}$ and Lu Shi ${ }^{4}$ \\ 1 First Affiliated Hospital of Xi'an Jiaotong University, Xi'an 710061, China \\ 2 Samuel Curtis Johnson Graduate School of Management, Cornell University, Ithaca, NY 14853, USA; \\ chaoling.feng@gmail.com \\ 3 Department of Health Policy and Management, University of Georgia, Athens, GA 30609, USA; \\ dzhang@uga.edu \\ 4 Department of Public Health Sciences, Clemson University, Clemson, SC 29631, USA; \\ HSPITLE@clemson.edu (H.S.); lus@clemson.edu (L.S.) \\ * Correspondence: bwsheng271@sina.com.cn \\ + This paper was done while Dr. Binwu Sheng was a visiting scholar at Clemson University under \\ supervision of Dr Liwei Chen and Dr. Lu Shi.
}

Academic Editor: Paul A. Scuffham

Received: 7 November 2016; Accepted: 19 January 2017; Published: 13 February 2017

\begin{abstract}
Background: The link between body weight status and spinal diseases has been suggested by a number of cross-sectional and cohort studies with a limited range of patient populations. No population-representative samples have been used to examine the link between obesity and spinal diseases. The present study is based on a nationally representative sample drawn from the Medical Expenditure Panel Survey. Methods: Using the cross-sectional sample of the 2014 Medical Expenditure Panel Study, we built four weighted logistic regression analyses of the associations between body weight status and the following four spinal diseases: low back pain, spondylosis, other cervical disorders and intervertebral disc disorder (IDD). Each respondent's body weight status was used as the key independent variable with three categories: normal/underweight, overweight, and obese. We controlled for marital status, gender, age, smoking status, household income, health insurance coverage, educational attainment and the use of health services for other major categories of diseases. Results: A total sample of 23,048 respondents was used in our analysis. Overweight and obese respondents, as compared to normal/underweight respondents, were more likely to develop lower back problems (Overweight: logged odds $=0.218, p<0.01$; Obese: logged odds $=0.395, p<0.001$ ) and IDD (Overweight: logged odds $=0.441, p<0.05$; Obese: logged odds $=0.528, p<0.001$ ). The associations between bodyweight status and spondylitis were statistically insignificant (Overweight: logged odds $=0.281, p=0.442$; Obese: logged odds $=0.680, p=0.104)$. The associations between body weight status and other cervical disorders (Overweight: logged odds $=-0.116, p=0.304$; Obese: logged odds $=-0.160, p=0.865$ ) were statistically insignificant. Conclusions: As the first study using a national sample to study bodyweight and spinal diseases, our paper supports the hypothesis that obesity adds to the burden of low back pain and IDD. Longitudinal and interventional studies are needed to understand the specific mechanisms behind these positive associations.
\end{abstract}

Keywords: obesity; low back pain; disc degeneration; spondylosis; cervical diseases; spinal disease

\section{Introduction}

Obesity is a rising public health concern in the U.S [1,2]. Ogden et al. [3] reported that the prevalence of obesity in the U.S. was $36.5 \%$ among adults and $17 \%$ among children and youth during 2011-2014. Obesity is associated with many prevalent conditions including prostate disease [4], 
cardiovascular diseases [5], diabetes [6], and osteoarthritis [7,8]. A number of studies have found a consistent association between obesity and low back pain (LBP) [9-13]. Koyangi, et al. [9] conducted a cross-sectional study of data collected from nine countries as part of the Collaborative Research on Ageing in Europe (COURAGE) study and found significantly higher odds for LBP among those with higher levels of body mass index (BMI). Similar associations between high levels of body mass index (BMI) and LBP were found by Heuch et al. [14] while Smuck et al. [15] found the risk of LBP increases as BMI increases. Among those suffering from chronic pain disorders, pain arising from various structures of the spine accounts for a majority of those affected and the lifetime prevalence of spinal pain has been reported as ranging from $54 \%$ to $80 \%$ [16]. LBP has tended to be the leading cause of disability worldwide [17]. In the U.S., LBP and costs related to treatment of LBP are escalating and the prevalence of LBP continues to increase [18]. Ferreira et al. [13] and Shiri et al. [11] found a dose-response relationship between obesity and low back pain-the more obese the individual the higher the odds for LBP and the greater the intensity of back pain.

Studies conducted by Heuch et al. [14], Smuck et al. [15] and Wertli et al. [19] found that high values of BMI consistently predispose individuals to chronic LBP. For instance, in Heuch et al.'s study [14], the odds ratio for BMI 30 or more vs. BMI less than 25 was 1.34 (95\% confidence interval (CI), 1.08-1.67) for men and 1.22 (95\% CI, 1.03-1.46) for women after adjusting for confounding factors. Knutsson et al. [20] found a linear positive relationship between BMI and lumbar spinal stenosis. Several studies suggest that high BMI and obesity may be linked to lumbar disc degeneration [17,21-26]. Takatalo et al. [25] note that BMI is commonly used as a standardized measure to assess overweight and obesity, although BMI does not indicate specifically the distribution of body fat and muscle mass. In the majority of the studies cited in this review, BMI was calculated as weight in kilograms divided by height in meters squared using the standard World Health Organization (WHO) definition $[9,11,25]$. Studies using BMI as an index of obesity specify cutoffs indicating levels of obesity, with overweight typically ranging from $25-29.9 \mathrm{~kg} / \mathrm{m}^{2}$ and obesity as $\geq 30 \mathrm{~kg} / \mathrm{m}^{2}$. Obesity, particularly the distribution of adiposity in the trunk of the body, is strongly linked to biomechanical changes that damage the spine and contribute to a range of spinal diseases including intervertebral disc degeneration, spinal stensosis, reduce disc height, herniation of the disc, hypertrophy of the spinal ligaments, osteoarthritis, and increased compression forces on disc surfaces [20,27-29]. To more fully explore in impact of obesity on the entire spine, Teraguchi et al. [24] investigated the prevalence and distribution of intervertebral disc degeneration over the entire spine and found the age and obesity were associated with the presence of disc degeneration in all areas of the spine, indicating that obesity places stress across multiple regions of back. BMI and obesity have also been identified as a risk factor for adjacent segment diseases and post-operative complications among patients undergoing lumbar fusion for degenerative spine diseases [30-40]. Weight control before and after the surgery was observed to reduce the incidence of adjacent segment disease and improve the fusion surgery outcome [41,42].

Thus far, research on the link between obesity and spine diseases has relied on exploratory studies used small, unrepresentative patient samples, and narrowly focused on lumber disc degeneration [21,22,43-45]. In this study, we analyzed 2014 Medical Expenditure Panel Study (MEPS) data, a nationally representative dataset based on the U.S. population, to explore the association between BMI and the presence of a broad range of spine disc degeneration conditions, including intervertebral disc disorder, spondylosis, other cercal and lower back degeneration.

\section{Materials and Methods}

We analyzed the cross-sectional sample of the 2014 Medical Expenditure Panel Study (MEPS) [46] to explore the association between adult's bodyweight status and spinal diseases. We chose the data source of MEPS since its cross-sectional sample provides a representative sample for the U.S. population, and contains information about the International Classification of Diseases (ICD) codes indicated in the description of the respondents' patterns of health care utilization. The dataset was publicly available with survey weights calculated to facilitate the analysis. 
With survey weights provided by MEPS, implemented through STATA's svy command [47] (Stata Corp., College Station, TX, USA), we built four weighted logistic regression analyses of the following four spinal diseases: low back pain (ICD 9: 724), spondylosis (ICD 9: 721), other cervical disorders (ICD 9: 723) and intervertebral disc disorder (ICD 9: 722). We add a fifth weighted logistic regression model with the binary dependent variable built as "any spinal disease": a patient who had any of the four conditions was coded as 1 in this variable and a patient who had none of the four conditions was coded as 0 . In each of the five weighted logistic regressions, each respondent's body weight status was used as the key independent variable with three BMI-based categories: normal or under (BMI < 25), overweight $(25 \leq \mathrm{BMI}<30)$, and obese (BMI $>30)$. This is consistent with the categorization in previous studies such as Heuch et al. [14].

Using a weighted logistic regression model we also controlled for marital status, gender, age, smoking status, household income, health insurance coverage, educational attainment and the use of health services for other major categories of diseases (diabetes, mental disease, skin disease, cancer, asthma and pneumonia).

\section{Results}

A total of 23,048 cases were used in our analyses due to the missing values in the 2014 MEPS cross-sectional dataset. The descriptive statistics of the independent variables and dependent variables used in our logistic regression analyses were charted by Tables 1 and 2. As Table 2 shows, of the four conditions we studied, low back pain was the most common problem (7.4\%), following by intervertebral disc disorder (1.7\%), other cervical disorder (1.3\%) and spondylosis $(0.2 \%)$. In total, $9.7 \%$ of the sample has at least one of the four spinal diseases.

Table 1. Descriptive statistics about independent variables in the analysis sample $(N=23,048)$.

\begin{tabular}{lcc}
\hline \multicolumn{1}{c}{ Variable } & Percentage & Mean (Standard Deviation) \\
\hline Age & $52.2 \%$ & $46.0(17.4)$ \\
Female & $88.2 \%$ \\
Living a metropolitan statistical & $50.9 \%$ \\
area & $82.2 \%$ \\
Married & $11.0 \%$ \\
Not smoking & $17.0 \%$ \\
Diabetes & $8.1 \%$ \\
Mental disease & $1.3 \%$ \\
Skin problem & $17.4 \%$ \\
Pneumonia & $5.7 \%$ \\
Asthma & \\
Cancer & $56.7 \%$ \\
\hline Insurance status & $21.3 \%$ \\
Private insurance & $22.0 \%$ \\
Public insurance & \\
No insurance & $16.1 \%$ \\
\hline Region & $18.5 \%$ \\
Northeast & $38.3 \%$ \\
Midwest & $27.1 \%$ \\
South &
\end{tabular}


Table 1. Cont.

\begin{tabular}{lcc}
\hline \multicolumn{1}{c}{ Variable } & Percentage & Mean (Standard Deviation) \\
\hline Educational attainment & \\
Below high school & $21.1 \%$ & \\
High school diploma only & $30.1 \%$ & \\
Some college & $26.1 \%$ \\
College or above & $22.8 \%$ \\
\hline Household income & \\
SFederal poverty line (FPL) & $24.5 \%$ \\
125\%-200\% of FPL & $16.9 \%$ \\
200\%-400\% of FPL & $29.5 \%$ \\
Above 400\% FPL & $29.0 \%$ \\
\hline Weight status & \\
Normal or underweight & $33.8 \%$ \\
Overweight & $34.5 \%$ \\
Obese & $31.7 \%$ \\
\hline
\end{tabular}

Table 2. Percentage of Spinal Diseases in the Analysis Sample $(\mathrm{N}=23,048)$.

\begin{tabular}{cccccc}
\hline & $\begin{array}{c}\text { Any Spinal } \\
\text { Disease }\end{array}$ & Low Back Pain & Spondylosis & $\begin{array}{c}\text { Other Cervical } \\
\text { Disorder }\end{array}$ & $\begin{array}{c}\text { Intervertebral } \\
\text { Disc Disorder }\end{array}$ \\
\hline Percentage & $9.7 \%$ & $7.4 \%$ & $0.2 \%$ & $1.3 \%$ & $1.7 \%$ \\
\hline
\end{tabular}

The logistic regression analyses (Table 3) showed that overweight and obese respondents, as compared to normal or underweight respondents, were more likely to develop lower back problems (Overweight: Odds ratio $=1.244, p<0.01$; Obese: $\mathrm{OR}=1.484, p<0.001$ ) and intervertebral disc disorders (Overweight: $\mathrm{OR}=1.554, p<0.05$; Obese: $\mathrm{OR}=1.696, p<0.001$ ). The association between bodyweight and spondylosis, though also positive, was statistically insignificant (Overweight: $\mathrm{OR}=1.324, p=0.442$; Obese: $\mathrm{OR}=1.974, p=0.104)$. The association between obesity and other cervical disorders (Overweight: $\mathrm{OR}=0.890, p=0.304$; Obese: $\mathrm{OR}=0.852, p=0.865$ ) is also insignificant.

Table 3. Weighted logistic regressions of bodyweight status and spinal diseases $(\mathrm{N}=23,048)$.

\begin{tabular}{|c|c|c|c|c|c|}
\hline \multirow[t]{2}{*}{ Variables } & $\begin{array}{c}\text { Any Spinal } \\
\text { Disease }\end{array}$ & $\begin{array}{c}\text { Lower } \\
\text { Back Pain }\end{array}$ & Spondylosis & $\begin{array}{c}\text { Other Cervical } \\
\text { Disorder }\end{array}$ & $\begin{array}{l}\text { Intervertebral } \\
\text { Disc Disorder }\end{array}$ \\
\hline & Odds Ratio & Odds Ratio & Odds Ratio & Odds Ratio & Odds Ratio \\
\hline Age & $\begin{array}{l}1.012 * * * \\
(0.000)\end{array}$ & $\begin{array}{l}1.012 * * * \\
(0.000)\end{array}$ & $\begin{array}{l}1.029 * * \\
(0.006)\end{array}$ & $\begin{array}{l}1.009 * \\
(0.016)\end{array}$ & $\begin{array}{l}1.009 * * \\
(0.007)\end{array}$ \\
\hline \multicolumn{6}{|c|}{ Race (Latinos as reference) } \\
\hline White & $\begin{array}{c}1.327^{* * * *} \\
(0.000)\end{array}$ & $\begin{array}{l}1.169 * \\
(0.040)\end{array}$ & $\begin{array}{l}5.709 * \\
(0.022)\end{array}$ & $\begin{array}{l}1.613 * * \\
(0.010)\end{array}$ & $\begin{array}{c}2.020 * * * \\
(0.000)\end{array}$ \\
\hline Black & $\begin{array}{c}0.993 \\
(0.932)\end{array}$ & $\begin{array}{c}0.958 \\
(0.626)\end{array}$ & $\begin{array}{l}4.137 \\
(0.080)\end{array}$ & $\begin{array}{c}0.762 \\
(0.268)\end{array}$ & $\begin{array}{l}1.489 * \\
(0.049)\end{array}$ \\
\hline Other & $\begin{array}{c}1.029 \\
(0.775)\end{array}$ & $\begin{array}{c}0.985 \\
(0.890)\end{array}$ & $\begin{array}{l}2.901 \\
(0.295)\end{array}$ & $\begin{array}{c}1.035 \\
(0.895)\end{array}$ & $\begin{array}{c}1.616 \\
(0.054)\end{array}$ \\
\hline \multicolumn{6}{|c|}{ Education (below school as reference) } \\
\hline High school & $\begin{array}{l}1.181 * \\
(0.023)\end{array}$ & $\begin{array}{c}1.151 \\
(0.084)\end{array}$ & $\begin{array}{c}0.376 \\
(0.061)\end{array}$ & $\begin{array}{c}1.331 \\
(0.170)\end{array}$ & $\begin{array}{l}1.366 \\
(0.069)\end{array}$ \\
\hline Some college & $\begin{array}{c}1.334^{* * *} \\
(0.000)\end{array}$ & $\begin{array}{l}1.311 * * \\
(0.001)\end{array}$ & $\begin{array}{c}1.155 \\
(0.755)\end{array}$ & $\begin{array}{l}1.502 \\
(0.055)\end{array}$ & $\begin{array}{l}1.449 * \\
(0.039)\end{array}$ \\
\hline
\end{tabular}


Table 3. Cont.

\begin{tabular}{|c|c|c|c|c|c|}
\hline \multirow[t]{2}{*}{ Variables } & $\begin{array}{c}\text { Any Spinal } \\
\text { Disease }\end{array}$ & $\begin{array}{c}\text { Lower } \\
\text { Back Pain }\end{array}$ & Spondylosis & $\begin{array}{c}\text { Other Cervical } \\
\text { Disorder }\end{array}$ & $\begin{array}{l}\text { Intervertebral } \\
\text { Disc Disorder }\end{array}$ \\
\hline & Odds Ratio & Odds Ratio & Odds Ratio & Odds Ratio & Odds Ratio \\
\hline College \& above & $\begin{array}{l}1.336^{* * *} \\
(0.000)\end{array}$ & $\begin{array}{l}1.328 * * \\
(0.002)\end{array}$ & $\begin{array}{c}0.459 \\
(0.168)\end{array}$ & $\begin{array}{c}1.422 \\
(0.122)\end{array}$ & $\begin{array}{l}1.522 * \\
(0.031)\end{array}$ \\
\hline \multicolumn{6}{|c|}{ Insurance (private as reference) } \\
\hline Public insurance & $\begin{array}{c}1.122 \\
(0.078)\end{array}$ & $\begin{array}{l}1.165^{*} \\
(0.037)\end{array}$ & $\begin{array}{c}0.619 \\
(0.263)\end{array}$ & $\begin{array}{c}0.742 \\
(0.098)\end{array}$ & $\begin{array}{l}1.338 * \\
(0.039)\end{array}$ \\
\hline No insurance & $\begin{array}{l}0.774^{* * *} \\
(0.001)\end{array}$ & $\begin{array}{l}0.798^{* *} \\
(0.008)\end{array}$ & $\begin{array}{c}0.153 \\
(0.070)\end{array}$ & $\begin{array}{c}0.744 \\
(0.141) \\
\end{array}$ & $\begin{array}{c}0.803 \\
(0.227)\end{array}$ \\
\hline Not smoking & $\begin{array}{c}0.737^{* * * *} \\
(0.000)\end{array}$ & $\begin{array}{c}0.783^{* * * *} \\
(0.000)\end{array}$ & $\begin{array}{l}0.485 * \\
(0.038)\end{array}$ & $\begin{array}{c}0.890 \\
(0.465) \\
\end{array}$ & $\begin{array}{c}0.535^{* * *} \\
(0.000)\end{array}$ \\
\hline Not married & $\begin{array}{l}0.857^{* *} \\
(0.002)\end{array}$ & $\begin{array}{l}0.870 * \\
(0.013)\end{array}$ & $\begin{array}{c}0.899 \\
(0.744) \\
\end{array}$ & $\begin{array}{c}1.020 \\
(0.876) \\
\end{array}$ & $\begin{array}{l}0.778 * \\
(0.025)\end{array}$ \\
\hline \multicolumn{6}{|c|}{ Weight (normal/under as reference) } \\
\hline Overweight & $\begin{array}{l}1.257^{* * * *} \\
(0.000)\end{array}$ & $\begin{array}{l}1.244 * * \\
(0.001)\end{array}$ & $\begin{array}{l}1.324 \\
(0.504) \\
\end{array}$ & $\begin{array}{c}0.890 \\
(0.426) \\
\end{array}$ & $\begin{array}{l}1.554 * * \\
(0.001)\end{array}$ \\
\hline Obese & $\begin{array}{c}1.456^{* * *} \\
(0.000)\end{array}$ & $\begin{array}{c}1.484^{* * *} \\
(0.000)\end{array}$ & $\begin{array}{c}1.974 \\
(0.091)\end{array}$ & $\begin{array}{c}0.852 \\
(0.293)\end{array}$ & $\begin{array}{c}1.696^{* *} \\
(0.000)\end{array}$ \\
\hline
\end{tabular}

Notes: Standard errors of logistic regression coefficients are in parentheses. $p$-values in parentheses: ${ }^{*} p<0.05$, ${ }^{* *} p<0.01,{ }^{* * *} p<0.001$. The models also control the four geographical regions and whether the respondent lived in a metropolitan statistical area, plus the respondent's utilization of health care.

When we used the recoded measure of "having any spinal disease" as the dependent variable of a weighted logistic regression, both overweight $(\mathrm{OR}=1.257, p<0.001)$ and obese $(\mathrm{OR}=1.456, p<0.001)$ had a statistically significant positive association with this outcome variable.

\section{Discussion}

Our finding about the association between obesity and spinal diseases was consistent with findings from prior studies [48-52]. In one prior study, a modest but positive association between obesity and low back pain (LBP), in particular chronic LBP, was identified in a cross-sectional survey data study of 29,424 twin subjects [53]. Among patients diagnosed with spinal diseases, higher BMI was associated with increased disability, more severe pain symptoms, and comorbid conditions [54]. Our study did not find significant correlation between obesity and cervical diseases, which was also consistent with findings of prior studies [34,55-58]. This could possibly be explained by the fact that cervical segment need not bear as much bodyweight as the lower segments such lumbar segments [59,60], while it is also possible that the small sample size of cervical diseases (as seen even in our large-sample study) does not provide enough power to detect any significant association in most research samples. Using STATA's module of powerlog [61], our power analysis shows that a sample size of 213,081 is needed to detect the significant pattern between spondylosis and overweight status. However, in our study the highly significant associations between higher bodyweight status and "having any spinal disease" suggests that the significant patterns between those specific conditions and bodyweight status are unlikely to be a mere statistical anomaly.

The possible effect of obesity on degenerative disc diseases (DDD), as observed in our study, could be exerted through several structural mechanisms. Obesity could result in serious postural changes that affect loading on joints, and thus result in long-term adverse effects on bones and joints $[62,63]$. Increased body mass index increases lumbosacral angles, which results in biomechanical changes in the lumbosacral spine resulting in greater flexion of the sacroiliac joints, greater facet degeneration, higher torque on the lumbar discs and joints, and increasing sheer forces that may overload the joints [28,29]. 
These biomechanical changes may produce higher compressive forces contributing to LBP. Obesity could also induce other mechanical-structural alterations, including joint misalignment $[64,65]$, and decreased ambulation and conditioning [66,67].

The metabolic mechanism could also be affected via the linkage between obesity and pain disorders. Whether obesity is an independent risk factor for the development of neuropathic pain disorders is not fully understood, but it is known that overweight individuals have an increased risk of various metabolic disorders, which could lead to increased risks of neuropathic disorders associated with conditions such as diabetes [68]. In other words, obesity and its associated metabolic disorders may increase the risk of peripheral neuropathic disorders [69]. In one study, after controlling for other major risk factors including duration of Type 1 diabetes and glycosylated hemoglobin values, diabetes patients with higher BMI was also found to have higher cumulative incidence of neuropathic conditions $[70,71]$.

In addition, a possible link between obesity and disc degeneration of the spine could also be found among obese patients with the chronic inflammatory conditions. Obesity has been found to be associated with a chronic low-grade inflammatory response characterized by abnormal cytokine production, increased acute phase reactants, as well as activation of inflammatory signaling pathways in the adipose tissue [72], and it has been observed that expansion of adipose tissue during weight gain is linked with inflammatory macrophages through chemokines. Recent reports indicate that adipose tissue functions as an endocrine organ in which adipocytes and recruited macrophages produce cytokines such as tumor necrosis factor (TNF), interleukin 6 (IL-6) and adipokines such as adiponectin, leptin, and resistin, which are thought to be associated with obesity, insulin resistance, and other inflammatory disorders [73]. Leptin and resistin are pro-inflammatory, and have a strong effect on increasing IL-2 secretion and proliferation and memory T cells to produce interferon $\gamma$ production, which could further aggravate lower disc degeneration [74,75]. Obesity has also been suggested to be correlated with cartilage inflammation [76]. From a genetic perspective, patients with DDD have low-grade systemic inflammation [77], while fat mass and obesity-associated gene (FTO) is an IDD predisposition gene and may lead to a positive correlation between obesity and DDD. In a study of a Chinese Han population, it has been suggested that the single nucleotide polymorphisms rs 11076008 of FTO may have played an important role in the development of DDD and IDD [78,79]. Thus, obesity has been linked to both biomechanical and metabolic changes that contribute to LBP.

Our study has several limitations. Although the size and breadth of our sample provides a reasonable estimation of the impact of obesity on a selected range of spinal diseases, the precision and accuracy of our analysis depends on the accuracy of the ICD-9-CM coding. Recent studies in human and animal models have suggested that validating ICD coding with imaging data could make a strong study $[69,73,80,81]$, as these studies address the issue of possible coding errors. Second, the obesity-DDD association from this study should be interpreted with caution, since it does not reject the "reverse causality" hypothesis (the spinal conditions could increase the risk for obesity as juvenile disc degeneration was strongly associated with diminished physical functioning [6] and diminished physical functioning could mean less energy expenditure). Moreover, with available evidence suggesting a likely relationship between increased BMI and a variety of pain conditions, the question remains as to whether the link we identified here was specific to spinal conditions [82]. It is possible that individuals who experienced ongoing pain may reduce their activity levels and therefore experience weight gain and eventual deconditioning, which might lead to a vicious circle of further increasing pain. Data with longitudinal follow-up about the physical activity information will be needed to examine this possible pathway between spinal diseases and obesity.

The use of MEPS data limits the generalizability of our results to the civilian non-institutionalized population in the U.S. Excluded from this database are those residing in nursing homes or long term care facilities, who may represent a high percentage of those suffering from chronic spinal disorders? The results of this study may underestimate the costs and impact of obesity on spinal diseases resulting in LBP. 


\section{Conclusions}

This is the first study using population-representative national data to show that the intervertebral disc disorder and chronic LBP are linked with obese and overweight bodyweight status. Although we are unable to tell the exact causal mechanism behind these associational patterns given the cross-sectional nature of our data, our finding that obesity predicts spinal diseases in the lower back but not in the cervical region provides more support for the mechanical-structural hypothesis than for metabolic or behavioral hypothesis. From a policy and management viewpoint, if the causal link between spinal disease and obesity is further substantiated by longitudinal and interventional studies, the health care expenditure associated with obesity might be even higher than the current estimates [83-86] and thus the cost-benefit ratio of obesity interventions might be more favorable that what has been estimated so far [87-91]. In other words, further research is needed where researchers employ longitudinal analyses or interventional studies examining whether weight loss leads to improvement of spinal conditions. This would more precisely determine the links between levels of obesity and specific spinal conditions, as well as a fuller understanding of the benefits from obesity interventions.

Author Contributions: Binwu Sheng was responsible for drafting the Introduction and Conclusions; Chaoling Feng and Donglan Zhang were responsible for interpreting the results; Lu Shi was responsible for analyzing the data and organizing the manuscript; and Hugh Spitler was responsible for literature review in the Introduction part and the discussion part, plus finalizing the writing.

Conflicts of Interest: The authors declare no conflict of interest.

\section{References}

1. Kopelman, P.G. Obesity as a medical problem. Nature 2000, 404, 635-643. [PubMed]

2. Ogden, C.L.; Carroll, M.D.; Kit, B.K.; Flegal, K.M. Prevalence of Obesity in the United States, 2009-2010; NCHS Data Brief; NCHS: Atlanta, GA, USA, 2012; pp. 1-8.

3. Ogden, C.L.; Carroll, M.D.; Fryar, C.D.; Flegal, K.M. Prevalence of Obesity among Adults and Youth: United States, 2011-2014; NCHS Data Brief; NCHS: Atlanta, GA, USA, 2015; pp. 1-8.

4. Zhang, J.Q.; Geng, H.; Ma, M.; Nan, X.Y.; Sheng, B.W. Metabolic Syndrome Components are Associated with Increased Prostate Cancer Risk. Int. Med. J. Exp. Clin. Res. 2015, 21, 2387-2396. [CrossRef] [PubMed]

5. Ortega, F.B.; Lavie, C.J.; Blair, S.N. Obesity and Cardiovascular Disease. Circ. Res. 2016, 118, $1752-1770$. [CrossRef] [PubMed]

6. Ingaramo, R.A. Obesity, Diabetes, and Other Cardiovascular Risk Factors in Native Populations of South America. Curr. Hypertens. Rep. 2016, 18, 9. [CrossRef] [PubMed]

7. Sowers, M. Epidemiology of risk factors for osteoarthritis: Systemic factors. Curr. Opin. Rheumatol. 2001, 13, 447-451. [CrossRef] [PubMed]

8. Hinton, R.; Moody, R.L.; Davis, A.W.; Thomas, S.F. Osteoarthritis: Diagnosis and therapeutic considerations. Am. Fam. Physician 2002, 65, 841-848. [PubMed]

9. Koyanagi, A.; Stickley, A.; Garin, N.; Miret, M.; Ayuso-Mateos, J.L.; Leonardi, M.; Koskinen, S.; Galas, A.; Haro, J.M. The association between obesity and back pain in nine countries: A cross-sectional study. BMC Public Health 2015, 15, 123. [CrossRef] [PubMed]

10. Heuch, I.; Heuch, I.; Hagen, K.; Zwart, J.A. A Comparison of Anthropometric Measures for Assessing the Association between Body Size and Risk of Chronic Low Back Pain: The HUNT Study. PLoS ONE 2015, 10, e0141268. [CrossRef] [PubMed]

11. Shiri, R.; Lallukka, T.; Karppinen, J.; Viikari-Juntura, E. Obesity as a risk factor for sciatica: A meta-analysis. Am. J. Epidemiol 2014, 179, 929-937. [CrossRef] [PubMed]

12. Brooks, C.; Siegler, J.C.; Marshall, P.W. Relative abdominal adiposity is associated with chronic low back pain: A preliminary explorative study. BMC Public Health 2016, 16, 700. [CrossRef] [PubMed]

13. Ferreira, P.H.; Beckenkamp, P.; Maher, C.G.; Hopper, J.L.; Ferreira, M.L. Nature or nurture in low back pain? Results of a systematic review of studies based on twin samples. Eur. J. Pain 2013, 17, 957-971. [CrossRef] [PubMed] 
14. Heuch, I.; Heuch, I.; Hagen, K.; Zwart, J.A. Body mass index as a risk factor for developing chronic low back pain: A follow-up in the Nord-Trondelag Health Study. Spine 2013, 38, 133-139. [CrossRef] [PubMed]

15. Smuck, M.; Kao, M.C.; Brar, N.; Martinez-Ith, A.; Choi, J.; Tomkins-Lane, C.C. Does physical activity influence the relationship between low back pain and obesity? Spine J. 2014, 14, 209-216. [CrossRef] [PubMed]

16. Manchikanti, L.; Singh, V.; Falco, F.J.; Benyamin, R.M.; Hirsch, J.A. Epidemiology of low back pain in adults. Neuromodulation 2014, 17 (Suppl. 2), 3-10. [CrossRef] [PubMed]

17. Wilson Zingg, R.; Kendall, R. Obesity, Vascular Disease, and Lumbar Disk Degeneration: Associations of Comorbidities in Low Back Pain. PMER 2016. [CrossRef]

18. Manchikanti, L.; Singh, V.; Datta, S.; Cohen, S.P.; Hirsch, J.A. Comprehensive review of epidemiology, scope, and impact of spinal pain. Pain Physician 2009, 12, E35-E70. [PubMed]

19. Wertli, M.M.; Held, U.; Campello, M.; Schecter Weiner, S. Obesity is associated with more disability at presentation and after treatment in low back pain but not in neck pain: Findings from the OIOC registry. BMC Musculoskelet. Disord. 2016, 17, 140. [CrossRef] [PubMed]

20. Knutsson, B.; Sanden, B.; Sjoden, G.; Jarvholm, B.; Michaelsson, K. Body Mass Index and Risk for Clinical Lumbar Spinal Stenosis: A Cohort Study. Spine 2015, 40, 1451-1456. [CrossRef] [PubMed]

21. Rodriguez-Martinez, N.G.; Perez-Orribo, L.; Kalb, S.; Reyes, P.M.; Newcomb, A.G.; Hughes, J.; Theodore, N.; Crawford, N.R. The role of obesity in the biomechanics and radiological changes of the spine: An in vitro study. J. Neurosurg. Spine 2016, 24, 615-623. [CrossRef] [PubMed]

22. Dario, A.B.; Ferreira, M.L.; Refshauge, K.M.; Lima, T.S.; Ordonana, J.R.; Ferreira, P.H. The relationship between obesity, low back pain, and lumbar disc degeneration when genetics and the environment are considered: A systematic review of twin studies. Spine J. 2015, 15, 1106-1117. [CrossRef] [PubMed]

23. Li, Z.; Liang, J.; Wu, W.K.; Yu, X.; Yu, J.; Weng, X.; Shen, J. Leptin activates RhoA/ROCK pathway to induce cytoskeleton remodeling in nucleus pulposus cells. Int. J. Mol. Sci. 2014, 15, 1176-1188. [CrossRef] [PubMed]

24. Teraguchi, M.; Yoshimura, N.; Hashizume, H.; Muraki, S.; Yamada, H.; Minamide, A.; Oka, H.; Ishimoto, Y.; Nagata, K.; Kagotani, R.; et al. Prevalence and distribution of intervertebral disc degeneration over the entire spine in a population-based cohort: The Wakayama Spine Study. Osteoarthr. Cartil. 2014, 22, 104-110. [CrossRef] [PubMed]

25. Takatalo, J.; Karppinen, J.; Taimela, S.; Niinimaki, J.; Laitinen, J.; Sequeiros, R.B.; Samartzis, D.; Korpelainen, R.; Nayha, S.; Remes, J.; et al. Association of abdominal obesity with lumbar disc degeneration-A magnetic resonance imaging study. PLoS ONE 2013, 8, e56244. [CrossRef] [PubMed]

26. Xu, X.; Li, X.; Wu, W. Association Between Overweight or Obesity and Lumbar Disk Diseases: A Meta-Analysis. Clin. Spine Surg. 2015, 28, 370-376. [CrossRef] [PubMed]

27. Urquhart, D.M.; Kurniadi, I.; Triangto, K.; Wang, Y.; Wluka, A.E.; O’Sullivan, R.; Jones, G.; Cicuttini, F.M. Obesity is associated with reduced disc height in the lumbar spine but not at the lumbosacral junction. Spine 2014, 39, E962-E966. [CrossRef] [PubMed]

28. Onyemaechi, N.O.; Anyanwu, G.E.; Obikili, E.N.; Onwuasoigwe, O.; Nwankwo, O.E. Impact of overweight and obesity on the musculoskeletal system using lumbosacral angles. Patient Preference Adher. 2016, 10, 291-296. [CrossRef] [PubMed]

29. Rodriguez-Martinez, E.; Nava-Ruiz, C.; Escamilla-Chimal, E.; Borgonio-Perez, G.; Rivas-Arancibia, S. The Effect of Chronic Ozone Exposure on the Activation of Endoplasmic Reticulum Stress and Apoptosis in Rat Hippocampus. Front. Aging Neurosci. 2016, 8, 245. [CrossRef] [PubMed]

30. De la Garza-Ramos, R.; Bydon, M.; Abt, N.B.; Sciubba, D.M.; Wolinsky, J.P.; Bydon, A.; Gokaslan, Z.L.; Rabin, B.; Witham, T.F. The impact of obesity on short- and long-term outcomes after lumbar fusion. Spine 2015, 40, 56-61. [CrossRef] [PubMed]

31. McGuire, K.J.; Khaleel, M.A.; Rihn, J.A.; Lurie, J.D.; Zhao, W.; Weinstein, J.N. The effect of high obesity on outcomes of treatment for lumbar spinal conditions: Subgroup analysis of the spine patient outcomes research trial. Spine 2014, 39, 1975-1980. [CrossRef] [PubMed]

32. Burgstaller, J.M.; Held, U.; Brunner, F.; Porchet, F.; Farshad, M.; Steurer, J.; Ulrich, N.H.; Group, L.S. The Impact of Obesity on the Outcome of Decompression Surgery in Degenerative Lumbar Spinal Canal Stenosis: Analysis of the Lumbar Spinal Outcome Study (LSOS): A Swiss Prospective Multicenter Cohort Study. Spine 2016, 41, 82-89. [CrossRef] [PubMed] 
33. Higgins, D.M.; Mallory, G.W.; Planchard, R.F.; Puffer, R.C.; Ali, M.; Gates, M.J.; Clifton, W.E.; Jacob, J.T.; Curry, T.B.; Kor, D.J.; et al. Understanding the Impact of Obesity on Short-term Outcomes and In-hospital Costs After Instrumented Spinal Fusion. Neurosurgery 2016, 78, 127-132. [CrossRef] [PubMed]

34. Giannadakis, C.; Nerland, U.S.; Solheim, O.; Jakola, A.S.; Gulati, M.; Weber, C.; Nygaard, O.P.; Solberg, T.K.; Gulati, S. Does Obesity Affect Outcomes After Decompressive Surgery for Lumbar Spinal Stenosis? A Multicenter, Observational, Registry-Based Study. World Neurosurg. 2015, 84, 1227-1234. [CrossRef] [PubMed]

35. Cao, J.; Kong, L.; Meng, F.; Zhang, Y.; Shen, Y. Impact of obesity on lumbar spinal surgery outcomes. J. Clin. Neurosci. 2016, 28, 1-6. [CrossRef] [PubMed]

36. Lingutla, K.K.; Pollock, R.; Benomran, E.; Purushothaman, B.; Kasis, A.; Bhatia, C.K.; Krishna, M.; Friesem, T. Outcome of lumbar spinal fusion surgery in obese patients: A systematic review and meta-analysis. Bone Jt. J. 2015, 97, 1395-1404. [CrossRef] [PubMed]

37. Buerba, R.A.; Fu, M.C.; Gruskay, J.A.; Long, W.D., 3rd; Grauer, J.N. Obese Class III patients at significantly greater risk of multiple complications after lumbar surgery: An analysis of 10,387 patients in the ACS NSQIP database. Spine J. 2014, 14, 2008-2018. [CrossRef] [PubMed]

38. Rihn, J.A.; Kurd, M.; Hilibrand, A.S.; Lurie, J.; Zhao, W.; Albert, T.; Weinstein, J. The influence of obesity on the outcome of treatment of lumbar disc herniation: Analysis of the Spine Patient Outcomes Research Trial (SPORT). J. Bone Jt. Surg. Am. Vol. 2013, 95, 1-8. [CrossRef] [PubMed]

39. Sing, D.C.; Yue, J.K.; Metz, L.N.; Winkler, E.A.; Zhang, W.R.; Burch, S.; Berven, S.H. Obesity Is an Independent Risk Factor of Early Complications After Revision Spine Surgery. Spine 2016, 41, E632-E640. [CrossRef] [PubMed]

40. Soroceanu, A.; Diebo, B.G.; Burton, D.; Smith, J.S.; Deviren, V.; Shaffrey, C.; Kim, H.J.; Mundis, G.; Ames, C.; Errico, T.; et al. Radiographical and Implant-Related Complications in Adult Spinal Deformity Surgery: Incidence, Patient Risk Factors, and Impact on Health-Related Quality of Life. Spine 2015, 40, 1414-1421. [CrossRef] [PubMed]

41. Ou, C.Y.; Lee, T.C.; Lee, T.H.; Huang, Y.H. Impact of body mass index on adjacent segment disease after lumbar fusion for degenerative spine disease. Neurosurgery 2015, 76, 396-401. [CrossRef] [PubMed]

42. Yadla, S.; Malone, J.; Campbell, P.G.; Maltenfort, M.G.; Harrop, J.S.; Sharan, A.D.; Vaccaro, A.R.; Ratliff, J.K. Obesity and spine surgery: Reassessment based on a prospective evaluation of perioperative complications in elective degenerative thoracolumbar procedures. Spine J. 2010, 10, 581-587. [CrossRef] [PubMed]

43. Samartzis, D.; Karppinen, J.; Chan, D.; Luk, K.D.; Cheung, K.M. The association of lumbar intervertebral disc degeneration on magnetic resonance imaging with body mass index in overweight and obese adults: A population-based study. Arthritis Rheum. 2012, 64, 1488-1496. [CrossRef] [PubMed]

44. Samartzis, D.; Karppinen, J.; Mok, F.; Fong, D.Y.; Luk, K.D.; Cheung, K.M. A population-based study of juvenile disc degeneration and its association with overweight and obesity, low back pain, and diminished functional status. J. Bone Jt. Surg. Am. Vol. 2011, 93, 662-670. [CrossRef] [PubMed]

45. Longo, U.G.; Denaro, L.; Spiezia, F.; Forriol, F.; Maffulli, N.; Denaro, V. Symptomatic disc herniation and serum lipid levels. Eur. Spine J. 2011, 20, 1658-1662. [CrossRef] [PubMed]

46. Cohen, J.W.; Cohen, S.B.; Banthin, J.S. The medical expenditure panel survey: A national information resource to support healthcare cost research and inform policy and practice. Med. Care 2009, 47 (Suppl. S1), S44-S50. [CrossRef] [PubMed]

47. Kreuter, F.; Valliant, R. A survey on survey statistics: What is done and can be done in Stata. Stata J. 2007, 7, 1-21.

48. Liuke, M.; Solovieva, S.; Lamminen, A.; Luoma, K.; Leino-Arjas, P.; Luukkonen, R.; Riihimaki, H. Disc degeneration of the lumbar spine in relation to overweight. Int. J. Obes. 2005, 29, 903-908. [CrossRef] [PubMed]

49. Andersen, R.E.; Crespo, C.J.; Bartlett, S.J.; Bathon, J.M.; Fontaine, K.R. Relationship between body weight gain and significant knee, hip, and back pain in older Americans. Obes. Res. 2003, 11, 1159-1162. [CrossRef] [PubMed]

50. Michel, A.; Kohlmann, T.; Raspe, H. The association between clinical findings on physical examination and self-reported severity in back pain. Results of a population-based study. Spine 1997, 22, 296-303. [CrossRef] [PubMed] 
51. Webb, R.; Brammah, T.; Lunt, M.; Urwin, M.; Allison, T.; Symmons, D. Prevalence and predictors of intense, chronic, and disabling neck and back pain in the UK general population. Spine 2003, 28, 1195-1202. [CrossRef] [PubMed]

52. Deyo, R.A.; Bass, J.E. Lifestyle and low-back pain. The influence of smoking and obesity. Spine 1989, 14, 501-506. [CrossRef] [PubMed]

53. Leboeuf-Yde, C.; Kyvik, K.O.; Bruun, N.H. Low back pain and lifestyle. Part II-Obesity. Information from a population-based sample of 29,424 twin subjects. Spine 1999, 24, 779-783. [CrossRef] [PubMed]

54. Fanuele, J.C.; Abdu, W.A.; Hanscom, B.; Weinstein, J.N. Association between obesity and functional status in patients with spine disease. Spine 2002, 27, 306-312. [CrossRef] [PubMed]

55. Sato, S.; Yagi, M.; Machida, M.; Yasuda, A.; Konomi, T.; Miyake, A.; Fujiyoshi, K.; Kaneko, S.; Takemitsu, M.; Machida, M.; et al. Reoperation rate and risk factors of elective spinal surgery for degenerative spondylolisthesis: Minimum 5-year follow-up. Spine J. 2015, 15, 1536-1544. [CrossRef] [PubMed]

56. Singh, S.; Kumar, D.; Kumar, S. Risk factors in cervical spondylosis. J. Clin. Orthop. Trauma 2014, 5, $221-226$. [CrossRef] [PubMed]

57. Samal, S.; Panigrahi, P.; Dutta, A. Social epidemiology of excess weight and central adiposity in older Indians: Analysis of Study on global ageing and adult health (SAGE). BMJ Open 2015, 5, e008608. [CrossRef] [PubMed]

58. Smith, K.B.; Smith, M.S. Obesity Statistics. Prim. Care 2016, 43, 121-135. [CrossRef] [PubMed]

59. Wang, Y.; Wang, L.; Du, C.; Mo, Z.; Fan, Y. A comparative study on dynamic stiffness in redtypical finite element model and multi-body model of redC6-C7 cervical spine segment. Int. J. Numer. Methods Biomed. Eng. 2016. [CrossRef] [PubMed]

60. Carrier, C.S.; Bono, C.M.; Lebl, D.R. Evidence-based analysis of adjacent segment degeneration and disease after ACDF: A systematic review. Spine J. 2013, 13, 1370-1378. [CrossRef] [PubMed]

61. Collier, T. Review of Alan Acock's a Gentle Introduction to Stata. Stata J. 2015, 15, 588-593.

62. Fabris de Souza, S.A.; Faintuch, J.; Valezi, A.C.; Sant'Anna, A.F.; Gama-Rodrigues, J.J.; de Batista Fonseca, I.C.; de Melo, R.D. Postural changes in morbidly obese patients. Obes. Surg. 2005, 15, 1013-1016. [CrossRef] [PubMed]

63. Rodacki, A.L.; Fowler, N.E.; Provensi, C.L.; Rodacki Cde, L.; Dezan, V.H. Body mass as a factor in stature change. Clin. Biomech. 2005, 20, 799-805. [CrossRef] [PubMed]

64. Felson, D.T.; Goggins, J.; Niu, J.; Zhang, Y.; Hunter, D.J. The effect of body weight on progression of knee osteoarthritis is dependent on alignment. Arthritis Rheum. 2004, 50, 3904-3909. [CrossRef] [PubMed]

65. Sharma, L.; Lou, C.; Cahue, S.; Dunlop, D.D. The mechanism of the effect of obesity in knee osteoarthritis: The mediating role of malalignment. Arthritis Rheum. 2000, 43, 568-575. [CrossRef]

66. Yamakawa, K.; Tsai, C.K.; Haig, A.J.; Miner, J.A.; Harris, M.J. Relationship between ambulation and obesity in older persons with and without low back pain. Int. J. Obes. Relat. Metab. Disord. 2004, 28, 137-143. [CrossRef] [PubMed]

67. Verbunt, J.A.; Seelen, H.A.; Vlaeyen, J.W.; van de Heijden, G.J.; Heuts, P.H.; Pons, K.; Knottnerus, J.A. Disuse and deconditioning in chronic low back pain: Concepts and hypotheses on contributing mechanisms. Eur. J. Pain 2003, 7, 9-21. [CrossRef]

68. Lean, M.E. Pathophysiology of obesity. Proc. Nutr. Soc. 2000, 59, 331-336. [CrossRef] [PubMed]

69. Miscio, G.; Guastamacchia, G.; Brunani, A.; Priano, L.; Baudo, S.; Mauro, A. Obesity and peripheral neuropathy risk: A dangerous liaison. J. Peripher. Nerv. Syst. 2005, 10, 354-358. [CrossRef] [PubMed]

70. De Block, C.E.; De Leeuw, I.H.; Van Gaal, L.F. Impact of overweight on chronic microvascular complications in type 1 diabetic patients. Diabetes Care 2005, 28, 1649-1655. [CrossRef] [PubMed]

71. Tesfaye, S.; Chaturvedi, N.; Eaton, S.E.; Ward, J.D.; Manes, C.; Ionescu-Tirgoviste, C.; Witte, D.R.; Fuller, J.H. Vascular risk factors and diabetic neuropathy. N. Engl. J. Med. 2005, 352, 341-350. [CrossRef] [PubMed]

72. Wang, Y.; Huang, F. N-3 Polyunsaturated Fatty Acids and Inflammation in Obesity: Local Effect and Systemic Benefit. BioMed Res. Int. 2015, 2015, 581469. [CrossRef] [PubMed]

73. Hamminga, E.A.; van der Lely, A.J.; Neumann, H.A.; Thio, H.B. Chronic inflammation in psoriasis and obesity: Implications for therapy. Med. Hypotheses 2006, 67, 768-773. [CrossRef] [PubMed]

74. Tilg, H.; Moschen, A.R. Adipocytokines: Mediators linking adipose tissue, inflammation and immunity. Nat. Rev. Immunol. 2006, 6, 772-783. [CrossRef] [PubMed] 
75. Lord, G.M.; Matarese, G.; Howard, J.K.; Baker, R.J.; Bloom, S.R.; Lechler, R.I. Leptin modulates the T-cell immune response and reverses starvation-induced immunosuppression. Nature 1998, 394, 897-901. [PubMed]

76. Xie, Q.; Wei, M.; Kang, X.; Liu, D.; Quan, Y.; Pan, X.; Liu, X.; Liao, D.; Liu, J.; Zhang, B. Reciprocal inhibition between miR-26a and NF-kappaB regulates obesity-related chronic inflammation in chondrocytes. Biosci. Rep. 2015, 35, e00204. [PubMed]

77. Weber, K.T.; Alipui, D.O.; Sison, C.P.; Bloom, O.; Quraishi, S.; Overby, M.C.; Levine, M.; Chahine, N.O. Serum levels of the proinflammatory cytokine interleukin- 6 vary based on diagnoses in individuals with lumbar intervertebral disc diseases. Arthritis Res. Ther. 2016, 18, 3. [CrossRef] [PubMed]

78. Lao, L.; Zhong, G.; Li, X.; Liu, Z. A preliminary association study of fat mass and obesity associated gene polymorphisms and degenerative disc disease in a Chinese Han population. J. Int. Med. Res. 2014, 42, 205-212. [CrossRef] [PubMed]

79. Wu, Z.; Yang, Y.; Qiu, G. Association study between the polymorphisms of the fat mass- and obesity-associated gene with the risk of intervertebral disc degeneration in the Han Chinese population. Genet. Test. Mol. Biomark. 2013, 17, 756-762. [CrossRef] [PubMed]

80. Velmurugan, G.V.; Huang, H.; Sun, H.; Candela, J.; Jaiswal, M.K.; Beaman, K.D.; Yamashita, M.; Prakriya, M.; White, $\mathrm{C}$. Depletion of $\mathrm{H}_{2} \mathrm{~S}$ during obesity enhances store-operated $\mathrm{Ca}^{2+}$ entry in adipose tissue macrophages to increase cytokine production. Sci. Signal. 2015, 8, ra128. [CrossRef] [PubMed]

81. Khimich, S. Level of sensitivity of pain in patients with obesity. Acta Chir. Hung. 1997, 36, 166-167. [PubMed]

82. Janke, E.A.; Collins, A.; Kozak, A.T. Overview of the relationship between pain and obesity: What do we know? Where do we go next? J. Rehabil. Res. Dev. 2007, 44, 245-262. [CrossRef] [PubMed]

83. Li, Q.; Blume, S.W.; Huang, J.C.; Hammer, M.; Graf, T.R. The Economic Burden of Obesity by Glycemic Stage in the United States. Pharmacoeconomics 2015, 33, 735-748. [CrossRef] [PubMed]

84. Grieve, E.; Fenwick, E.; Yang, H.C.; Lean, M. The disproportionate economic burden associated with severe and complicated obesity: A systematic review. Obes. Rev. 2013, 14, 883-894. [CrossRef] [PubMed]

85. Wang, Y.C.; McPherson, K.; Marsh, T.; Gortmaker, S.L.; Brown, M. Health and economic burden of the projected obesity trends in the USA and the UK. Lancet 2011, 378, 815-825. [CrossRef]

86. Withrow, D.; Alter, D.A. The economic burden of obesity worldwide: A systematic review of the direct costs of obesity. Obes. Rev. 2011, 12, 131-141. [CrossRef] [PubMed]

87. Mathar, D.; Horstmann, A.; Pleger, B.; Villringer, A.; Neumann, J. Is it Worth the Effort? Novel Insights into Obesity-Associated Alterations in Cost-Benefit Decision-Making. Front. Behav. Neurosci. 2015, 9, 360. [CrossRef] [PubMed]

88. Sanchez-Santos, R.; Sabench Pereferrer, F.; Estevez Fernandez, S.; del Castillo Dejardin, D.; Vilarrasa, N.; Frutos Bernal, D.; Ruiz de Adana, J.C.; Masdevall Noguera, C.; Torres Garcia, A. Is the morbid obesity surgery profitable in times of crisis? A cost-benefit analysis of bariatric surgery. Cir. Esp. 2013, 91, 476-484. [CrossRef] [PubMed]

89. Dixon, J. Obesity: Health economics of bariatric surgery-Benefit versus cost. Nat. Rev. Endocrinol. 2012, 8, 632-633. [CrossRef] [PubMed]

90. Haby, M.M.; Vos, T.; Carter, R.; Moodie, M.; Markwick, A.; Magnus, A.; Tay-Teo, K.S.; Swinburn, B. A new approach to assessing the health benefit from obesity interventions in children and adolescents: The assessing cost-effectiveness in obesity project. Int. J. Obes. 2006, 30, 1463-1475. [CrossRef] [PubMed]

91. Martin, L.F.; White, S.; Lindstrom, W., Jr. Cost-benefit analysis for the treatment of severe obesity. World J. Surg. 1998, 22, 1008-1017. [CrossRef] [PubMed]

(C) 2017 by the authors; licensee MDPI, Basel, Switzerland. This article is an open access article distributed under the terms and conditions of the Creative Commons Attribution (CC BY) license (http://creativecommons.org/licenses/by/4.0/). 